\title{
SURINAAMSCHE VOLKSVERTELLINGEN.
}

\author{
DOOR
}

A. P. PENARD.

Onder het niet oorspronkelijke, uiterst gemengde en interessante deel der Surinaamsche bevolking, in welke het Negerelement het overwicht heeft, hoort men vaak de Anansi-tories of Spinverhalen vertellen, waarvan een twintigtal in deze verzameling voorkomen ${ }^{1}$ ). Wie ze verneemt zal moeten erkennen, dat de Surinamer zich in dit opzicht volstrekt niet achterlijk betoont.

Het is hier juist de plaats om twee onzer beroemdste sprookjesvertellers, beiden echte déddéhoso-alatta's (= sterfhuis-ratten) te herdenken. De eerste was Abrah a m Negentien, zoo genaamd omdat hij den grooten teen miste; de tweede Swieti-ba-Wieliblo-a-f aja-kier i-so-w oep, (d. i. Zoete-broer-Willy, blaas het licht uit zoo: woep!), dien de volksmond nog steeds bezingt met het volgende liedje dat hij op zich zelf dichtte:

\author{
$\mathrm{Na}$ te mi moni kom \\ Dan mi na Swieti ba Wieli; \\ $\mathrm{Na}$ te mi moni kaba \\ Dan na satan go-na-hel. \\ d. i.: 't Is als mijn geld komt \\ dan ben ik Zoete-broer-Willy, \\ maar als mijn geld op is, \\ dan is het: Satan-ga-naar-de-hel! \\ Koor: Love, love, love. \\ Love is very hard. \\ Waaraan Swieti ba Wieli het achtervoegsel van zijn naam \\ dankte, schijnt men niet met zekerheid te weten, maar ongetwijfeld \\ waren zoowel hij als zijn collega groote humoristen, wier komisch \\ voordragen tot nu toe diep in het geheugen hunner landgenooten
} geprent is.

1) Vgl. Dr. H. van Cappelle in deze Bijdragen, dl. 72 blz. 233. 
Anansitorie beteekent letterlijk vertellingen der spin en is tevens de naam, welke de bevolking aan alle sprookjes, verdichtsels, enz. geeft. Ba Anansi (Broer Spin) vervult in vele de hoofdrol en geldt dan als zinnebeeld van verleiding, veinzerij, leugen, bedrog, diefachtigheid en nog tal van andere ondeugden.

$\mathrm{Ba}$ Anansi treedt in de sprookjes op ais gewoon mensch, dikwijls in gezelschap van koningen en prinsessen, van bovennatuurlijke wezens en ook van verpersoonlijkte levenlooze voorwerpen, enz. Soms echter ook als de gewone spin met haar acht pooten. Wie echter met Ba Anansi wat te doen krijgt, trekt doorgaans aan het kortste eind, daar hij zich bedient van de zwarte kunst en dus tot veel in staat zou zijn. Soms laat zijn spreekwoordelijke sluwheid hem evenwel in den steek, maar zelfs in de moeilijkste gevallen blijft zijn verbazend geluk hem bij en kan hij dan ook steeds, ofschoon dikwijls deerlijk toegetakeld, naar de post'oro (beslagruimte) vluchten.

Gewoonlijk worden de Anansitories na zonsondergang verteld, vooral op den achtsten avond van een déddéhoso (sterfhuis) ter opvroolijking der treurenden. Doch het kan ook bij dag geschieden, indien de verteller er voor zorgt een ooghaartje uit te trekken, opdat hem geen kwaad overkome. Een ander staaltje van dergelijk bijgeloof is het volgende: Een oude negerin, die elken avond Anansitories in haar woning vertelde, vond er eens een boschspin, die volgens haar was komen luisteren hoe men de spin beloog. Zoo groot was de schrik van het oudje, dat ze voor altijd ophield met haar vertellingen.

Elke Anansitorie vormt een samenhangend geheel, dat in den regel een moraal bezit. Waar deze maar op een gebeurtenis in het dagelijksch leven van toepassing is, wordt de vertelling opgedist of aangehaald.

Onder de Anansitories komen er echter ook voor, die, hoewel interessant versurinaamscht, van vreemden oprsprong zijn, hetgeen bij een gemengde bevolking als de Surinaamsche lichtelijk te verwachten is.

Al de Anansitories beginnen met Eer tien tien, waarop zij, die niet naar den verteller willen luisteren, onmiddellijk Segré dien dien laten volgen.

Eer tien tien zou zooveel beteekenen als «eens, voor langen tijd, terwijl Segré dien dien maar een uitdrukking is, die rijmt op Eer tien tien. 
Onsamenhangende Anansitories worden door de toehoorders stop gezet met een z.g. kotie-siengi:

Tien bau, tien bau, (nabootsing van schoten), sani naki man trové, d.i. dingen slaan mannen neer.

Een andere koti-siengi luidt:

Grangran tie na mie gran tio

Grangran tie a lei agen.

d.i. Groot, groot tie - 't is mijn groot tio (oom)

Groot, groot tie - hij liegt alweer!

Is de Anansitorie langdradig, dan onderbreken de toehoorders die met een korte samenspraak, als volgt:

Eerste spreker: Een corjaal komt van Para.

Tweede spreker: Wat is er in de corjaal?

Eerste spreker: Een groote pagaal. En daarin bevindt zich een kleine pagaal. En in deze is er een nog kleiner pagaal. En in deze weer een kleinere enz.

Tweede spreker: En wat is er in de allerkleinste pagaal?

Eerste spreker: Een brief. En in dezen brief is een antwoord, bevattende de kotie siengi:

Fien fien, fien torie, ja a lei agen, a lei agen: haarfijn vertelsel, ja hij liegt alweer (bis).

$\mathrm{Om}$ ten volle van een Anansitorie te kunnen genieten, moet men die zelf hooren vertellen en het Negerengelsch goed begrijpen. Want de krachtvolle uitdrukkingen, het gedempt gefluister, de plotselinge uitroepen, de gesticulaties, de klank- en spraaknabootsingen, de korte liedjes, die er tusschen door gezongen worden, kortom de soeba soeba (saus of smakelijkheid) van de Anansitorie laat zich moeilijk beschrijven.

Het vertellen onzer Anansitories geraakt steeds meer in onbruik, omdat ze negerachtig worden gevonden en men aan de jeugd liever Europeesche vertellingen te genieten geeft zooals Roodkapje, Asschepoetster, e.d.

Zeker zijn er onder de Anansitories vele, die niet voor kinderooren deugen, maar men behoeft daarom niet alle af te keuren en er bestaat geen enkele reden om Ba Anansi door Reintje de Vos of andere te vervangen.

De Negerengelsche woorden in deze vertalingen zijn weergegeven volgens de Hollandsche uitspraak. De g echter moet als in het Engelsch uitgesproken worden. 
I. Hoe Ba Anansi een varken kreeg en verloor.

Eer tien tien, Sa Adjoeba (Sa = zus) bezat een varken, dat zoo vet als boter was geworden, waarom haar man Ba Anansi veel zin had het beest te slachten.

Telkens als Ba Anansi het vette varken van Sa Adjoeba zag, watertandde hij. Daarom drong hij er dikwijls bij haar op aan om het beest niet langer als een pronkstuk te houden, maar er een feestmaal van te bereiden voor de geheele Anansifamilie.

Maar Sa Adjoeba werd dan heel boos, wilde er niets van weten het dier te slachten en schold Anansi voor een onhebbelijken gulzigaard.

Ba Anansi ergerde zich en besloot Sa Adjoeba de gierigheid af te leeren en tevens het vette varken voor zich alleen te bemachtigen.

$\mathrm{Op}$ een goeden morgen hield $\mathrm{Ba}$ Anansi zich erg ziek. Hij kermde den geheelen dag, nu eens: "o i mijn buik», dan weer: oi mijn rug!»

Sa Adjoeba maakte zich ongerust en besloot 's nachts op te blijven om er dadelijk bij te zijn als haar man iets mocht overkomen.

Toen zij nu aan 't ziekbed waakte, deed Anansi alsof zijn toestand verslimmerde en begon eensklaps hardop te droomen: «Ba Anansi, mijn jongen, je moet een groot vet varken geheel alleen opeten. En niemand anders mag er een stukje van proeven, anders zal je sterven. Morgen al moet je het beest in het bosch naast de begraafplaats slachten, opdat je het daar ongestoord kan oppeuzelen. En niemand mag zien hoe je dit doet. Eerst dan zul je beter worden, begrijp je!"

Daarna hield $\mathrm{Ba}$ Anansi zich stil en sliep in.

Sa Adjoeba geloofde heilig aan droomen en dat wist de slimme Anansi. $\mathrm{Zij}$ beschouwde het daarom als haar plicht $\mathrm{Ba}$ Anansi's droom, welke zij met aandacht afgeluisterd had, stipt te vervullen. Daar Ba Anansi geen varken had en evenmin geld bezat, om er een te koopen, besloot zij morgen haar varken aan Anansi te geven, om hem van een wissen dood te redden. Als zij dit niet deed, zou zij Anansi's dood op haar geweten hebben en zijn geest zou haar komen plagen.

Eindelijk viel Sa Adjoeba van angst en vermoeidheid in een diepen slaap. 
Den volgenden morgen vroeg vertelde $\mathrm{Ba}$ Anansi aan Sa Adjoeba hoe zijn «doode moeder hem in den droom verschenen was en een middel tegen zijn ziekte had gegeven.

Sa Adjoeba vertelde toen bevende, dat zij den droom 's nachts gehoord had en bood ongevraagd haar varken aan. Maar Ba Anansi deed, alsof hij niets van Sa Adjoeba's aanbod wilde weten. Sa Adjoeba was zoo op haar varken gesteld. $\mathrm{Zij}$ moest het dier dus niet ter wille van hem dooden. Als hij stierf was dat zoo erg niet. Hij zou liever sterven, dan zoo'n offer van Sa Adjoeba vergen. Maar deze, bevreesd voor de geesten van Anansi en diens moeder, smeekte op haar knieën, dat Anansi het varken zou nemen en den raad van zijn doode moeder opvolgen.

$\mathrm{Na}$ zich lang door Sa Adjoeba te hebben laten smeeken, gaf Ba Anansi eindelijk toe en nam het varken naar het bosch, waar hij het wilde slachten. Doch juist zou hij dit doen, of daar weerklonk in de nabijheid de stem van een geest, roepende «wie daar!,

Op het hooren daarvan gaf Anansi verschrikt ten antwoord: «ik ben het, Ba Anansi. ,

Daarna vroeg de geest: «en wat doet $\mathrm{Ba}$ Anansi daar?» waarop Anansi hem inlichtte: "Ba Anansi slacht een varken.,

Toen riep de geest: «komt $\mathrm{Ba}$ Anansi helpen zijn varken slachten, komt $\mathrm{Ba}$ Anansi helpen zijn varken slachten», waarna duizenden geesten herhaalden: "komt $\mathrm{Ba}$ Anansi helpen zijn varken slachten!»

De geesten verschenen en slachtten ook Ba Anansi's varken, waarna zij weer verdwenen.

$\mathrm{Nu}$ wou $\mathrm{Ba}$ Anansi het varken gauw braden, doch weer klonk de stem van den geest: "wat doet $\mathrm{Ba}$ Anansi daar?» waarop deze antwoordde: ‘Ba Anansi wil het varken braden.» Daarna riep de geest: "komt $\mathrm{Ba}$ Anansi helpen het varken braden!" De andere geesten herhaalden dit, verschenen en hielpen Anansi het varken braden, waarna zij verdwenen evenals te voren.

$\mathrm{Nu}$ wou $\mathrm{Ba}$ Anansi met eten beginnen, maar ten derden male klonk de stem van den geest: "wat doet Ba Anansi daar?, Het antwoord was: « $\mathrm{Ba}$ Anansi wil van het varken eten, maar wenscht hierbij niet geholpen te worden.. Doch de geest stoorde zich hieraan niet en riep: "komt $\mathrm{Ba}$ Anansi helpen het varken op eten, komt Ba Anansi helpen het varken op eten!»

De gedienstige geesten kwamen wild door elkander schreeuwen- 
de: «komt Ba Anansi helpen het varken op eten, komt $\mathrm{Ba}$ Anansi helpen het varken op eten!,

En zij verslonden voor Ba Anansi's oogen het geheele varken, zonder hem zelfs een beentje te laten kluiven en verdwenen terstond weer.

Ba Anansi keerde bitter teleurgesteld huiswaarts en deelde zijn vrouw mee, hoe men hem het varken ontroofd had. Indien zij hem liefhad, moest zij maar een ander varken voor hem zien te krijgen.

Doch Sa Adjoeba geloofde Ba Anansi's verhaal niet, ofschoon deze op zijn platten buik wees als bewijs. $Z$ ij sprak bits dat hij nu maar gerust kon dood gaan en dat ze zich er niets van aantrok.

Anansi was dien nacht gedwongen met honger naar bed te gaan en had geleerd, dat oneerlijk verkregen goed meestal niet gedijt.

II. Waarom Ba Anansizoo bang voor vuur is.

(Liki fa Faja moi, na so Faja takroe toe $=$ zoo mooi als vuur is, zoo slecht is het ook).

Eer tien tien, Ba Anansi kwam Fa Faja (Vadertje Vuur) in het bosch tegen en aangetrokken door de mooie, heldere, roode kleur van den vurigen $\mathrm{Fa} F a j a$, noodigde hij dezen uit, om hem te komen opzoeken. Maar Fa Faja sloeg die uitnoodiging af. $\mathrm{Hij}$ wou niet gaarne bij Anansi op visite komen. "Want, zeide hij: "liki fa mi moi, na so mi takroe toe, (zoo mooi als ik ben, zoo slecht ben ik ook). Doch Anansi bleef zoo lang aandringen, dat Fa Faja eindelijk toegaf, zeggende: shet is goed, ik zal komen; maar ik kan niet over den blooten weg gaan, dus moet je van hier af tot naar je woning een tapijt van droge bladeren en takken voor mij leggen.» $\mathrm{Ba}$ Anansi voldeed aan het verlangen van $\mathrm{Fa}$ Faja en belegde den geheelen weg met het gevraagde tapijt, waarover Faja terstond naar $\mathrm{Ba}$ Anansi's huis ging.

Onderweg echter werd hij door het loopen over de droge bladeren en takken zóó groot, rood en heet, dat Anansi, toen hij hem zag naderen, verschrikt uitriep: "neen, Fa Faja, kom niet meer, kom niet meer!s.

Maar de warme vriend van Ba Anansi stoorde zich niet aan diens geroep en greep met zijn vlammen sissend Ba Anansi's huis aan.

Op het zien daarvan sprong Ba Anansi snel een zijraam uit, 
teneinde zich elders in de post'oro (beslagruimte) te verbergen, terwijl hij zijn vrouw en kinderen in huis achterliet, waar de heete Fa Faja ze verbrandde.

En sedert dien dag vlucht de spin naar de post'oro, zoodra zij maar een vonkje vuur ziet.

\section{Boesi- A n a n si.}

Eer tien tien, Ba Anansi zag het gouvernementsvaartuig "De Zwarte Ma Jaba». (Moeder Jaba) volgeladen aan den steiger liggen. Hij ging aan boord en zag er slechts één matroos op wacht. Ba Anansi haalde deze toen over om een paar borrels in een slijterij vlak tegenover den steiger met hem te gaan gebruiken. Instede van een paar bitters gaf hij den zeeman zooveel te drinken, dat de arme kerel smoordronken werd en in den winkel moest blijven liggen.

Ba Anansi begaf zich daarna weer aan boord, gooide de kabels los en stevende naar zee. Nu wist Ba Anansi, dat men op het fort Nieuw-Amsterdam alle voorbij varende schepen aanhield om op te nemen waarheen zij gingen of van waar zij kwamen.

Teneinde daarom de wachthebbende soldaten te verschalken, zong hij, het fort naderende, met luider stem: "Gramman foe Weste kondré, pasa-sa! Ooste nanga Weste a-saniman-pasa-sa. A fetiman pasa-sa! Poesoe him, poti him na wan see! De "Zwarte Ma Jaba» pasa-sa!» ${ }^{1}$ )

$\mathrm{Op}$ het hooren van $\mathrm{Ba}$ Anansi's gezang zouden de soldaten, denkende dat de Gouverneur aan boord was, de "zwarte $\mathrm{Ma}$ Jaba» ook ongemoeid hebben laten passeeren. Doch de kapitein van het gestolen schip ontdekte intusschen den diefstal en stelde den Gouverneur hiervan in kennis. Deze en de kapitein namen terstond met eenige politiebeambten plaats in een snelvarende boot ter vervolging van de "zwarte $\mathrm{Ma} \mathrm{Jaba}$, die kort na 't fort voorbij te zijn gegaan, werd ingehaald. De agenten grepen dadelijk de touwen langs de eene zijde van het schip, ten einde aan boord te klimmen, waarop Ba Anansi, die dit zag, aan de andere zijde te water sprong. Daarna zwom hij naar den onbewoonden oever van de rivier, vluchtte in het bosch en werd .... Boesi Anansi (boschspin).

1) D. i. Gouverneur van Westland, passeert! 'Oost- en West-dingenman (bezitter), passeert! De krijgsman passeert. Stoot hem, zet hem op een kant! De zwarte moeder Jaba passeert!

J)l. 80 . 


\section{Ieder volwassen man moet een rood} zitvlak hebben.

Eer tien tien, De Koning wou zijn reine, onschuldige dochter alleen ten huwelijk geven aan den man, die zonder dat het hem kwaad deed, een mand vol pepers kon opeten. De pepereter mocht zelfs geen lucht happen om den mond af te koelen, als de pepers hem brandden. Aan alle mannen van zijn gansche rijk stond de Koning toe te trachten op die wijze de prinses tot vrouw te krijgen, maar zij, wier pogingen mislukten, zouden onmiddellijk ter dood gebracht worden. En deze gevaarlijke voorwaarden schrikte iedereen af, waarom men algemeen geloofde, dat de prinses haar leven lang ongehuwd zou blijven.

Toch was er één, die moedig de peperproef wilde doorstaan, teneinde met de prinses te kunnen trouwen. Deze was Ba Anansi.

Hij ging naar het paleis teneinde den Koning zijn voornemen mede te deelen.

Maar voor de poort van het paleis gekomen begon hij met den mond een zuigende beweging te maken, net zoo als iemand doet, die door het gebruik van pepers den mond gebrand heeft. Ook in bijzijn van den Koning bleef Anansi deze beweging herhalen, waarmee hij wou doen uitkomen, dat dit zoo een gewoonte van hem was.

Toen de Koning vernam waarvoor Ba Anansi gekomen was, zeide hij minachtend: "nu al sta je zoo «ssh, sssh» te maken, wat zal je straks dan wel doen als je pepers eet?»

Ba Anansi verklaarde hierop: «daar moet gij niet op letten, mijn Koning, want het is een oude gewoonte van mij, die ik door het vele peper eten aangeleerd heb."

De Koning gebood daarna zijn ondergeschikten een groote mand met pepers te brengen, waarna hij $\mathrm{Ba}$ Anansi verlof gaf met de proef te beginnen. Ba Anansi zette zich ook naast de mand neer en het gelukte hem al de pepers daarin op te eten. Natuurlijk brandden de pepers hem hevig en koelde hij ook voortdurend den mond af met frissche lucht, zoo «ssh, sssh». Maar telkens als de Koning dit opmerkte, beweerde Ba Anansi, dat het zijn oude gewoonte was, gelijk hij reeds gezegd had. Ook werkten de pepers slecht op Ba Anansi's spijsvertering, zoodat hij zich dikwijls moest verwijderen. Het gevolg van al dat peper eten was, dat Anansi een heftige darmontsteking 
kreeg en de endeldarm voor een deel uit zijn lichaam trad en veel geleek op een groot rood gezwel.

$\mathrm{Ba}$ Anansi liet den Koning niets van dit alles merken. Hij zeide slechts, dat de peperproef hem zijn gewoonte om zoo "sssh, sssh» te maken geheel had afgeleerd, en hij had ook een grooten afkeer van pepers gekregen, waarom hij ze nooit meer zou eten. De Koning vond dit zeer begrijpelijk, hij prees $\mathrm{Ba}$ Anansi als den moedigsten man van het land. Hij gaf hem met plezier zijn dochter ten huwelijk en een rijken bruidsschat. $\mathrm{Na}$ het huwelijk bracht $\mathrm{Ba}$ Anansi de prinses naar zijn woning, die hij met 's Konings geld zoo weelderig mogelijk had ingericht. En daar deed hij al wat zijn koninklijk vrouwtje maar verlangde. Zij leefden dan ook geruimen tijd gelukkig met elkander.

Doch Ba Anansi ging elken morgen voor zonsopgang uit en keerde niet eerder weêr dan wanneer de zon reeds hoog aan den hemel stond.

Als de prinses informeerde waar hij geweest was, antwoordde $\mathrm{Ba}$ Anansi steeds ontwijkend en gaf tevens te kennen, dat hij niet wou nagegaan worden.

Door nieuwsgierigheid gedreven volgde de prinses op zekeren morgen $\mathrm{Ba}$ Anansi ongemerkt op diens geheimzinnigen tocht, teneinde hem te bespieden.

Ba Anansi liep regelrecht naar het zeestrand en beklom daar een hooge rots waar hij zich uitkleedde en zijn zitvlak naar de opkomende zon toekeerde, teneinde de verzwering zoo te genezen.

Nauwelijks had de prinses het groote, roode gezwel in de zon zien schitteren of zij riep van schrik: «Mijn Jezus, Ba Anansi, wat is er met je gebeurd!» - Op het hooren hiervan schrok Ba Anansi hevig, want hij dacht dat de prinses met haar gegil zijn gebrek bekend zou maken en men zou gaan onderzoeken hoe hij eraan gekomen was.

Haastig kleedde Anansi zich weer aan, klom van de rots en voegde zich schijnbaar kalm bij de prinses, zeggende: "wat doe je zoo dan, mijn prinsesje, wil je voor niemendal de geheele buurt in opschudding brengen met je gegil? 》

De prinses verklaarde toen dat zij bij het zien van het groote, roode gezwel zeer geschrikt was en dacht dat hem een ongeluk was overkomen. Anansi antwoordde: "maar mijn schat, als een man groot is, moet zijn zitvlak er zoo uitzien, vraag het maar 
aan je vader als je me niet gelooft. Hij bezat intusschen de zekerheid dat Zijn Majesteit zich op reis bevond.

De prinses, die niet wist dat de Koning afwezig was, begaf zich naar het paleis, teneinde haar vader te vragen, of Anansi wel de waarheid had gesproken.

Nauwelijks was zij verdwenen, of Ba Anansi nam een korteren weg door het bosch naar 's Konings woning, waar hij vóor zijn vrouw aankwam.

Als schoonzoon van den Koning liet men Ba Anansi overal in het paleis toe, zoodat hij zonder moeite in 's Konings slaapkamer kwam. Daar ging hij op 't bed liggen en bedekte zijn geheele lichaam met dekens behalve de roode plek in kwestie, die duidelijk te zien was.

Toen begon hij het gesnork van den Koning na te bootsen. Anansi wist dat de Koning er een hekel aan had in den slaap gestoord te worden en dat zijn vrouw dit uit eerbied voor haar vader ook niet zou doen.

Zoo wachtte Ba Anansi op de prinses. Deze trad even later ook de kamer binnen, waar zij hardop tot zichzelf sprak, zóó dat $\mathrm{Ba}$ Anansi het duidelijk verstond: *ach mijn vader slaapt, maar kijk, hij heeft net zulk een rooden plek als Ba Anansi. Ik behoef hem niet wakker te maken. Anansi had dus gelijk en ik zal hem om verontschuldiging moeten vragen voor mijn wangedrag». - Zoodra de prinses zich verwijderd had, sprong Ba Anansi het bed uit, kleedde zich aan en snelde langs den korteren weg naar huis terug, waar hij voor het venster plaats nam.

$\mathrm{Na}$ een poosje kwam de prinses aanzetten en vroeg hem weenend om vergiffenis. "Vergeef $\mathrm{mij}$, mijn schat $\mathrm{Ba}$ Anansi, dat ik je gewantrouwd heb, ik zal het nooit meer doen, maar ik heb in mijn onschuld niet kunnen gelooven, dat dit zoo bij alle mannen was:.

Daarop beloofde Ba Anansi zijn prinses te zullen vergeven, mits zij den Koning niets van het voorgevallene vertelde. Het paste een dochter niet met haar vader over zulke dingen te spreken.

De prinses zwoer daarop, dat zij geen woord meer over 't 't gebeurde zou reppen.

Toen omhelsde $\mathrm{Ba}$ Anansi zijn prinses en het geschil werd zoo in der minne opgelost. 


\section{Smitti Anansi, Timré Anansi of Bakri Anansi. (Smeed-, Timmer- of Bakkerspin).}

Eer tien tien, Ba Anansi klaagde aan Fa Tiegri (Vader Tijger), den eigenaar van een grooten kostgrond, zijn nood, dat hij en zijn familie niets te eten hadden en gebrek leden. Fa Tiegri gaf hierop aan $\mathrm{Ba}$ Anansi uit medelijden een mand vol cassaven. Ba Anansi dankte zijn weldoener voor dit geschenk en bracht het gauw naar huis. Maar deze goed gevulde mand aten Ba Anansi en de zijnen zoo gauw leeg, dat er in minder dan geen tijd niets van de aardvruchten meer over was. Toen zeide hij tot zijn kinderen: «kijk eens, als ik Fa Tiegri weer zoo gauw om wat cassaven vraag, weet ik zeker dat hij ze ons weigeren zal en daar we 't voedsel hoog noodig hebben, moeten wij desnoods geweld gebruiken ten einde het te krijgen. Weet jelui wat je doet, je houdt je schuil in de piena-palmen van Fa Tiegri's kostgrond en begint zoodra hij daar aan zijn werk zal zijn de boomen te schudden, alsof er een hevige wind waait, hierbij herhaaldelijk schreeuwende: "help, ò, help, ò, de wind waait mannen de lucht in!» En jullie houdt er niet mee op tot ik een sein geef. Je zult dan wel verder zien wat er gebeurt."

De kleine Anansies gehoorzaamden hun vader. Toen Fa Tiegri in zijn kostgrond kwam, zag hij de nabijstaande piena-palmen schudden als door een rukwind bewogen en hoorde tevens het hulpgeroep: "help, ò, help, de wind waait mannen de lucht in!,

Terzelfder tijd verscheen Ba Anansi, die deed alsof hij er toevallig haastig voorbij ging, en hij sprak: «hoor je dat, Fa Tiegri, de wind waait mannen de lucht in, het is verschrikkelijk om aan te zien, ik ga dus gauw naar huis ten einde mijn vrouw en kinderen vast te binden, opdat de wind ze niet naar omhoog sleurt.» Dit zeide Ba :Anansi met nadruk, omdat hij wist, dat Fa Tiegri sterk maar niet moedig was.

En als Fa Tiegri van de ontzettende gebeurtenis hoorde, verzocht hij, gelijk Ba Anansi verwacht had, ook angstig: "dank je, dank je, Ba Anansi, bind mij ook voor je gaat, want ik zal mijzelf niet zoo stevig kunnen vastbinden en ik wil niet naar den Hemel gewaaid worden vóordat het mijn tijd is.»

Ba Anansi liet zich dit geen tweemaal zeggen, doch haalde uit zijn zak een touw, waarmee hij Fa Tiegri zóó goed aan een boom vastbond, dat hij zich onmogelijk zelf zou kunnen los- 
maken. Toen sprak hij: "hai ${ }^{1}$ ), nu heb ik je te pakken, Fa Tiegri, ik zal je kostgrond'leegplunderen en je dan hier laten sterven.»

Daarna riep $\mathrm{Ba}$ Anansi zijn kinderen uit hun schuilplaats. Dezen kwamen ook en met hun vader roofden zij al het eetbare uit den kostgrond en gingen heen, Fa Tiegri aan zijn lot overlatende. Fa Tiegri vloekte dat het een aard had, maar kon zich niet loswerken.

Zoo bleef hij aan den boom gebonden en smeekte alle voorbijgangers hem te bevrijden, maar daar ieder den geweldenaar vreesde, lieten zij hem onder voorwendsel van haast te hebben kalm blijven waar hij was.

Toch ging er eindelijk één langs, die medelijden met Fa Tiegri kreeg en dat was Mat' Kesikesi (Vriend Aap). Deze sneed het touw van den gevangene door, doch slechts op voorwaarde dat die hem dan ook geen leed zou doen.

$\mathrm{Na}$ aldus in vrijheid gesteld te zijn, vroeg $\mathrm{Fa}$ Tiegri aan Mat' Kesikesi of deze hem niet kon zeggen, waar Ba Anansi zich ophield, waarop Mat' Kesikesi hem een plaats ergens in het bosch beduidde. Zonder dezen echter te bedanken, spoedde $\mathrm{Fa}$ Tiegri zich direct naar de aangewezen plaats. Doch Fan-go (Blijfgaan), Ba Anansi's oudste zoon, zag hem daar aankomen en waarschuwde zijn vader: "pa, pa, Fa Tiegri komt!» waarop Ba Anansi zijn zoon gebood een groot vuur aan te leggen, en een paar smidsgereedschappen ten toon te spreiden. Hij zelf plaatste toen een houwer in 't vuur om heet te worden en wachtte zoo Fa Tiegri op, die woedend kwam aanzetten, brullende: "je bond mij aan dien boom om te verhongeren, ehn, Anansi? (is het niet, spin?) dus zal ik je thans ook zonder genade vermoorden.» Schijnbaar verwonderd loog Ba Anansi daarop: «ik weet niets van wat je daar zegt, Fa Tiegri, ik ben Smitti-Anansi en heb het te druk met smeden om aan wat anders te denken. Je bedoelt zeker een andere Anansi.»

$\mathrm{Na}$ 't hooren van zoo'n goed in mekaar gezette leugen, maakte Fa Tiegri zijn excuus en zeide dat Smitti-Anansi wel precies op dien anderen Anansi geleek, waarna hij op verzoek van Smitti-Anansi ging zitten, teneinde het vuur wat aan te blazen. $\mathrm{Fa}$ Tiegri kon dan meteen iets van het smidsvak leeren.

1) Uitroep van voldoening. 
Maar nauwelijks had Fa Tiegri den muil geopend om te blazen of Ba Anansi stak er den gloeienden houwer in en vluchtte.

Razend als een dolle, trok Fa Tiegri den heeten houwer uit zijn bek, die deerlijk gebrand was.

Zoodra de pijn wat over was, begaf hij zich op weg om Ba Anansi te zoeken. Om nu zijn doel te bereiken moest Fa Tiegri heel diep het bosch in. Maar eindelijk ontdekte hij toch de nieuwe woonplaats van zijn vijand. Doch Fan-go hem bemerkende, verwittigde weer zijn vader: "pa, pa, Fa Tiegri komt!»

Ba Anansi liet zich hierop een hamer, een paar spijkers en planken brengen. En terwijl hij voorwendde druk aan het timmeren te zijn, stormde Fa Tiegri driftig op hem toe en brulde: hai, ik heb je weer gepakt joe boi (jou knaapl) En ik zal zorgen dat je mij thans niet ontglipt. Je gaf voor Smitti Anansi te zijn en duwde mij dien gloeiend heeten houwer in den mond, niet waar? Welnu, je zult er ook met je leven voor boeten.»

Daarop sprak Ba Anansi met geveinsde verbazing: «wat bedoel je toch, Fa Tiegri? Je hebt den verkeerden Anansi voor je. Ik ben nooit Smitti Anansi geweest, ik ben Timré Anansi en timmer hier al jaren lang zwaar voor mijn brood, ik heb dus geen tijd om zoo iets te doen als je daar zegt.» Fa Tiegri verzocht hierop aan Timré Anansi om 't hem niet kwalijk te nemen. Hij had Timré Anansi voor Smitti Anansi aangezien, omdat beiden zoo zeer op elkander geleken.»

Fa Tiegri bleef toen nog wat kijken naar het timmerwerk, waarom Timré Anansi hem vroeg of hij niet een plank, die gespijkerd moest worden, even stevig kon vasthouden. Fa Tiegri leerde op die manier dan een beetje van 't timmervak. Fa Tiegri vond het goed en hield de plank met beide voorpooten vast. Maar Timré Anansi zorgde er wel voor den spijker mis te slaan en zoo Fa Tiegri's pooten aan de plank vast te spijkeren.

Huilend van pijn wilde $\mathrm{Fa}$ Tiegri zich daarna op Timré Anansi werpen, doch kon zijn pooten niet van de plank losrukken. En toen hij er aan dacht den spijker met zijn tanden uit te halen, had Timré Anansi zich reeds uit de voeten gemaakt. Fa Tiegri genas spoedig van de wond en ging er weer op uit om Ba Anansi te pakken te krijgen.

Dezen keer had Fa Tiegri nog veel dieper het bosch in te gaan om Ba Anansi te vinden. Maar hij liep onvermoeid door tot hij diens nieuwste verblijf vond. Doch Fan-go als gewoonlijk 
op wacht, ontdekte hem en riep wederom zijn vader toe: "pa, pa, Fa Tiegri komt!» Dit vernemende haastte Ba Anansi zich den oven heet te maken terwijl hij zijn zoon zond om een vat meel in huis te halen. Hiermee kneedde Ba Anansi vlug eenige broodjes, die hij vooraan in den heeten oven plaatste. Een poosje later verscheen $\mathrm{Fa}$ Tiegri luid brullend: $\gg \mathrm{Hai}$, dit is de derde keer, dat ik je te pakken heb, joe boi Anansi. Maar ditmaal zul je niet ontsnappen, hoor, want Ba Anansi of Smitti Anansi of Timré Anansi, die mijn handen aan de plank vastspijkerde, wie je ook moogt wezen, ik zal je op een vreeselijke manier verscheuren en verslinden.»

Op het hooren van Fa Tigri's bedreiging, zette Ba Anansi andermaal een verwonderd gezicht en verklaarde: "je ziet mij voor een andere Anansi aan Fa Tiegri want ik ben Bakri Anansi en bak sedert dat ik een jongeling was, reeds brood voor de geheele buurt en dit is zwaar werk, kijk eens hoe ik zweet, hoe zou ik dus voor Smitti Anansi en Timré Anansi kunnen spelen?»

Hierop gaf $\mathrm{Fa}$ Tiegri Bakri Anansi toe, Smitti Anansi en Timré Anansi zweetten niet zoo als hij, doch zij geleken zoo sprekend op hem, vandaar de vergissing, en Fa Tiegri bood dus zijn excuses aan. Daarna vroeg Bakri Anansi of hij niet een groot brood lustte, waarop Fa Tiegri van ja knikte. Bakri Anansi kneedde ook het brood, maar veinsde vermoeidheid en verzocht $\mathrm{Fa}$ Tiegri om het zelf in den oven te steken. Fa Tiegri mocht het echter niet vooraan doen, want hier was het te heet, dus zou 't van buiten branden eer 't van binnen gaar kon wezen. Derhalve moest Fa Tiegri het brood dieper in den oven plaatsen, waar het niet zoo heet was, en het langzaam naar voren trekken om bruin te worden, als het reeds half gebakken zou zijn; zoo deden alle bakkers. Niets kwaads vermoedende ging $\mathrm{Fa}$ Tiegri ook het brood achter in den oven leggen, waarop Bakri Anansi terstond de deur van den oven sloot. Na een poos haalde hij er Fa Tiegri's geroosterd lichaam uit.

Toen gaf $\mathrm{Ba}$ Anansi een groot diner, waarop hij de geheele buurt uitnoodigde en op tijgervleesch trakteerde. En als de gasten zich hieraan te goed deden, deelde $\mathrm{Ba}$ Anansi hun mede hoe hij er aan gekomen was. Natuurlijk vonden allen Anansi een held en geven hem groot gelijk. Hij moest maar gauw weer een ander heldenstuk uithalen en vooral niet vergeten hen weer te vragen. 
VI. Soekroementa.

(Zoete $\mathrm{min}$ ).

Eer tien tien, Er was eens een Koning, die drie mooie dochters had. En hij bracht ze zoo zedig op, dat ze niet eens met een man mochten spreken. De Koning wilde zelfs niet, dat er iets van mannen aan de prinsessen zou verteld worden. En wie dit verbod mocht overtreden, zou hij terstond laten doodschieten.

Toen dus 's Konings dochters volwassen geworden waren, wisten ze van mannen niet veel meer af, dan dat dezen een baard kregen en broeken aan hadden.

$\mathrm{Nu}$ hield $\mathrm{Ba}$ Anansi veel van jonge maagden en daarom was het ook begrijpelijk. dat de mooie, jonge, reine prinsessen zijn gedachten geheel in beslag namen. Ja, het lichaam begon hem te jeuken als hij maar aan haar dacht. Vaak sprak hij tot zichzelf: "Anansi, mijn jongen, als het zoo doorgaat, zullen de maagdelijke dochters van den Koning jou nog gek maken, je moet er dus maar wat op zien te vinden om tot kalmte te komen.,

Het was werkelijk een moeielijk geval voor Ba Anansi. De prinsessen te naderen was al zoo lastig, laat staan ze te liefkoozen.

Ba Anansi gaf echter den moed niet op en bleef naar een middel zoeken om bij zijn hooggeplaatste geliefden te komen, tot hij op een zekeren dag in de krant las, dat de oude ninné (kindermeid) der prinsessen overleden was en de Koning een andere ninné voor zijn dochters zocht.

«Ha!» riep Ba Anansi, «nu moet ik handelen!»

Zonder dralen verkleedde hij zich als een echte ninné in koto en jakie (rok en jak) en haastte zich naar het koninklijk paleis.

In het paleis gekomen maakte $\mathrm{Ba}$ Anansi een kosi (kniebuiging) voor den Koning en sprak eerbiedig:

"Ik ben je komen vragen, mijn Koning, of je me niet als ninné voor je dochters wilt huren.»

De Koning, die Ba Anansi voor een vrouw aanzag, vroeg wie ze was en welke aanbeveling zij had. "Want», zei de Koning, "mijn dochters vertrouw ik niet zoo blindelings toe aan de eerste de beste meid. Hierop loog de ninné 't volgende: «ik ben Sa Anansi, maar ik heb niemand hier om mij te recommandeeren, 
want ik ben een vreemde in dit land. Want zie je, mijn Koning, ik leefde in Takroeprakserie-kondré (Land van de slechte gedachte), en woonde daar met mijn broer samen. Doch deze hield van dat patjoka-patjoka (losbandig) leven met die motjo-meiden (lichtekooien) en dat kon ik niet verdragen. Daarom verzocht ik hem als een fatsoenlijk man te trouwen, waarvan hij niets wou hooren.

Ik vond het dus beter huis en land te verlaten, in plaats van een beroerte van ergernis in zijn handen te krijgen. Dàt is de reden van mijn komst naar hier, mijn Koning. » De Koning vroeg daarop of ninné geen matti (vriendin) of vrijer had, waarop zij, op zichzelf wijzende, antwoordde: «Ik, Adjoeba? En zij lachte dat zij er van schudde: "ga ga gaa!!» — "Als er iemand is die niet van $\mathrm{matt}$ is of $\mathrm{mattispel}$ (sentimenteele vriendschapsbetuigingen) houdt, dan ben ik dat zeker, mijn Koning. En vrijers zijn ook mijn "treef, en ze hebben, met uw verlof gezegd, zelfs geen broeken aan hun achterste. Zeg me eens, mijn Koning, waar zullen ze kleeren vinden om aan hun vrouwen te geven, ehn? En ik ben iemand, die bijzonder op mooie kleeren gesteld is. Maar afgezien daarvan, de mannen brengen dat kleine beetje geld dat ze verdienen niet thuis maar aan die motjo-meiden op straat. Neen dat leventje staat mij heelemaal niet aan, want ik ben een fatsoenlijke vrouw en ik houd van mijn kerk. En daarom mijn Koning, hoef je niet bevreesd te zijn, mij je dochters toe te vertrouwen.»

En zoo had ninné een prachtig verhaal opgedischt, zoodat de Koning er niet aan twijfelde of hij had een beste, brave meid voor zijn eerbare dochters gevonden. Hij stelde haar ook onmiddellijk aan en riep de prinsessen binnen, waarop de kennismaking volgde. De dochters waren zeer ingenomen met hun nieuwe $\mathrm{ninné} \mathrm{en} \mathrm{deden} \mathrm{tal} \mathrm{van} \mathrm{vragen} \mathrm{waarop} \mathrm{n}$ inné steeds bevestigend antwoordde.

Toen nam de Koning Sa Anansi ter zijde en fluisterde haar in het oor: "Zorg goed voor mijn prinsessen, hoor! En zie vooral toe dat geen man ze nadert, want anders....

"Ik weet, ik weet,» zoo viel $\mathrm{n}$ inné hem in de rede, *vrees niet, ik zal mijn plicht doen».

En hierna volgde zij haar nieuwe meesteressen naar de kamers. Zoo was nin né Anansi dan eindelijk alleen met de prinsessen. Zulk een goede ninné hadden de meisjes nog nooit gehad. 
$\mathrm{N}$ inné sliep naast haar bedden en hielp haar bij het baden. Hierbij streelde zij de prinsessen, hetgeen zij heerlijk vonden. Het duurde dan ook niet lang of de meisjes beschouwden $n$ in né meer als een zuster dan als een bediende. "Ninné», spraken zij, je moet niet meer naast, maar in ons bed slapen. En als we in 't bad gaan, moet je ook mee komen". Maar nu maakte de slimme $n$ in né bezwaren daartegen en zeide dat de Koning bij 't hooren daarvan al boos zou worden, waarop 's Konings dochters zwoeren nooit iets ervan aan haar vader te zullen vertellen.

Dienzelfden middag, toen de prinsessen zich ontkleedden om naar 't bad te gaan, verzochten zij ninné dat ook te doen. Deze deed alsof zij aarzelde en eerst nadat 's Konings dochters haar een heele poos gesmeekt hadden, gaf zij toe en ontkleedde zich ook. Maar nauwelijks had ninné dat gedaan of de prinsessen sloegen verbaasd de handen in elkaar en riepen uit: «Mijn God, kijk ninné: O! Ninné, mijn schat, wat zie je er anders uit!» En zij barstten toen alle drie in een schaterlachen uit. "Zie je» sprak ninné, schijnbaar boos, «ik wou mij niet ontkleeden, maar jullie hebt er mij toe gedwongen, en nu bespotten jullie mijn gebrek. Dat is niet aardig van jullie. Ik ben een mismaakte vrouw, maar het is God die mij zoo heeft geschapen. Ik heb mijn gebrek niet met geld gekocht».

Daarop vroegen de prinsessen $n$ inné om vergiffenis en beloofden haar niet meer uit te lachen. $\mathrm{Nu}$ begon het gestoei in het bad. Ninn é leerde aan de dochters des Konings allerlei spelletjes o. a. ook het z.g. So e kroementa-spel (minnekoozen). En dit gevaarlijk spel vonden de prinsessen het allerfijnst, zoodat zij het iederen dag wilden spelen. Het gevolg bleef niet lang weg. Ninné zag zich binnen korten tijd verplicht ontslag te vragen en nòch het verzoek des Konings, nòch de smeekbeden zijner dochters konden ninné van plan doen veranderen. $\mathrm{Ze}$ gaf voor, dat haar slechte broer in het land gekomen was, hetgeen haar verblijf in het paleis onmogelijk maakte. En zoo ging $n$ inné heen om als zoodanig nimmer weer terug te keeren.

Eenigen tijd na ninnés vertrek werden de prinsessen ziek en de doktores die de Koning liet halen om haar te onderzoeken, verklaarde dat het van het Soekroementa-spel kwam.

Het spreekt vanzelf, dat de Koning razend van drift was en als een krankzinnige te keer ging. Maar of hij al raasde en 
tierde, zijn dochters wilden hem niet verklappen van wie zij het heerlijke soekroementa-spel hadden geleerd.

Ten einde raad liet de Koning naar de gewezen ninné zoeken, om haar wegens plichtverzuim ter dood te veroordeelen, maar zooals men kan begrijpen, was die nergens te vinden. Toen ontbood de Koning n in nés broer die sprekend op ninné geleek, daar hij niemand anders dan Sa Anansi zelf was. Deze verklaarde natuurlijk niets van Sa Anansi af te weten. Hij kon dus weer vrij gaan en mompelde zoo binnensmonds: "Wie zijn kinderen in onwetenheid opvoedt, handelt even verkeerd, als die ze slechte lessen geeft.s

VII. Ba Anansi en de gulzige Matti Dagoe.

Eer tien tien, Ba Anansi en Mat' Dagoe (Vriend Hond) wandelden eens samen en zagen op den hoek van den weg een grooten boom, die beladen was met dokoens (rijstpuddingen), die er als vruchten in hingen.

De geurige dokoenvruchten deden hen watertanden. Ba Anansi smakte met de lippen en Mat' Dagoe likte aan zijn baard en beiden riepen tegelijk uit: "Hè, wat een heerlijke dokoens, dat is net iets voor ons, niet waar?»

Ba Anansi stelde Mat' Dagoe voor den boom te beklimmen, maar hoe deze ook probeerde, hij was daartoe niet in staat.

"Neen», zeide hij, "ik kan niet klimmen, jij moet dus maar aan 't plukken gaan, Ba Anansi. Gooi mij dan de dokoens toe, dan zal ik ze met den mond opvangen. Ik kan dat werkje goed en zal dus zorgen dat er geen op den grond valt. Vindt je dat goed Ba Anansi?»

Deze knikte van ja. Alleen moest Mat' Dagoe hem nog beloven, geen halve dohoen te zullen opeten, zoolang hij, Anansi, nog in den boom was.

Mat' Dagoe gaf hem zijn eerewoord hierop en zij spraken af de dokoens te zulien deelen als Anansi weer uit den boom was. Daarna wees Ba Anansi aan Mat' Dagoe een plekje vol droge bladeren om de dokoens te verbergen, opdat de voorbijgangers ze niet zouden stelen. Hij klom in den boom en ging vlijtig aan 't werk. Hij plukte de dokoens en wierp ze voor Mat' Dagoe, die ze behendig in den mond opving. Maar deze fijne vruchten gaven aan Mat' Dagoe's tong zoo'n heerlijken smaak, dat hij ze alle opslikte. 
Echter telkens deed Mat' Dagoe net of hij de dokoens op het plekje, dat Ba Anansi aangewezen had, onder de droge bladeren verborg. Zoo misleidde hij $\mathrm{Ba}$ Anansi, die voortging met plukken. Toen er eindelijk geen dokoens meer aan den boom hingen, begon Ba Anansi naar omlaag te komen waarbij hij zijn gezicht naar den stam gekeerd moest houden. Mat' Dagoe maakte van deze gelegenheid gebruik om zich uit de voeten te maken, daar hij de woede van Ba Anansi vreesde.

Maar Mat' Dagoe's overvolle buik bezwaarde hem zóó, dat hij door het snelle loopen buiten adem geraakte en in een droge sloot doodviel. Hier vond $\mathrm{Ba}$ Anansi hem een poosje later terug en nam het doode lichaam mee naar huis.

Thuisgekomen sneed $\mathrm{Ba}$ Anansi met zijn mes den buik van Mat' Dagoe's lijk open en nam er de dokoens uit die hij smakelijk opat.

Daarna braadde hij Mat' Dagoe's vleesch en smulde heerlijk, terwijl hij dacht:

«Wie door bedrog ten koste van anderen wil leven, loopt gevaar dit met eigen ondergang te boeten.»

VIII. Matti Tiengi-fowloe's troost.

(Vriend Stinkvogel's troost).

Eer tien tien, Ba Anansi ging uit visschen met twee exvaren visschers. Aan den zeekant gekomen, vingen zij zooveel visch als de boot bevatten kon. Ba Anansi, begeerig op den buit, zocht naar een middel om de visch voor zich te behouden. Hij wist dat de sterkere der twee visschers een onbetrouwbaar wezen was en hij haalde dezen over om den ander te vermoorden. "Als je dien man uit den weg ruimt, sprak Ba Anansi, dan behoeven wij de visschen niet met hem te deelen.» Door hebzucht gedreven, deed de oneerlijke medevisscher ook wat Ba Anansi voorstelde en doodde den zwakkeren kameraad. Daarna keerden hij en Anansi naar de stad terug, waar zij hun boot in de Drambrandersgracht vastlegden. $\mathrm{Nu}$ wou de visscher met het verdeelen van de vangst beginnen, maar $\mathrm{Ba}$ Anansi trad op hem toe en zei zacht: «je behoeft niets te deelen, alles is voor mij en als jou dat niet bevalt, dan klaag ik je aan als den moordenaar van onzen vriend.»

Op het hooren daarvan werd de visscher woedend, geraakte buiten zich zelf en schreeuwde zoo hard mogelijk «jou gongo- 
saman (konkelaar), als jij mij wilt aanklagen, dat ik den kerel vermoord heb, dan zal ik zeggen, hoe jij mij er toe bracht. En dan ben jij medeplichtig en even schuldig als ik. Neen, om mij bang te maken, moet jij nog eens geboren worden, domoor!»

't Spreekt vanzelf dat bij dit twisten de voorbijgangers bleven staan om te luisteren en te zien wat gebeuren zou. Intusschen was de moord bekend geworden en werd onmiddellijk de politie gewaarschuwd. Ba Anansi begreep het gevaar waarin hij zich bevond, en werd zeer driftig nu hij zijn plan zoo geheel zag mislukken. Toornig siste hij tusschen de opeengeklemde tanden: "maar jij zal toch geen der visschen vreten, gemeene moordenaar, aan de galg zal jij hangen.» En meteen vluchtte Ba Anansi naar de post'oro, waar het gerecht hem niet zou kunnen halen. Toen dus de politie kwam, vond deze alleen den moordenaar, die gearresteerd werd.

In optocht volgde de geheele menigte den arrestant naar het politiebureau, alwaar hij terstond ter dood veroordeeld werd. Iedereen was ingenomen met dit rechtvaardig vonnis en juichte van plezier. Alleen Mat' Tiengi-fowloe, het eenige familielid van den vermoorde, bleef maar doorjammeren. $\mathrm{Tj} \mathrm{e}^{1}$ ), waar zal ik nu troost vinden voor zooveel leed.

Een goede vriend van Mat' Tiengi-fowloe, diens geklaag vernemende, raadde hem uit medelijden aan naar de Drambrandersgracht te gaan.

Daar lag nog de boot vol met de rottende visschen en Mat' Tiengi-fowloe kon moeilijk een betere vertroosting vinden. Hij volgde ook den ontvangen raad en vloog heen, teneinde zich aan de visschen te goed te doen. "Zoo gaat het in het leven wel meer», dacht Mat' Tiengi-fowloe. "Zij vingen de visschen en vochten er om, terwijl ik nu kalmpjes er fijn van smuls:

IX. De Koning der verdachte geluiden.

Eer tien tien, Er was eens groot diner op het Gouvernement. Onder de aanwezigen bevond zich ook een groote t a i k oela koekoeber è ${ }^{2}$ ) mulat.

Plotseling klonk er aan tafel een onderdrukt geluid: "poewien», en meteen verspreidde zich een onaangename geur in de zaal.

Al de gasten knepen met den vinger den neus toe en aller

1) Jammerkreet.

2) Ruwgebouwde mulat met opgezetten buik. 
blik richtte zich op den mulat, die doodsbleek werd en angstig voor zich uitkeek. Zonder hem echter tijd te geven, iets te zeggen, snauwde de Gouverneur hem driftig toe: "Dus jij bent het, niet waar, jou vuile neger? Neen, voor zoo iets bestaat geen excuus. Iemand, die zich aldus op het Gouvernement kan laten hooren, is ook niet geschikt voor 's Lands dienst. Ik ontsla je dus op staanden voet.»

Hierna riep de Gouverneur de schildwachten, die op post stonden in de eetzaal en gebood hen, den smeerlap de deur uit te smijten. Deze gehoorzaamden en trapten den stinkzak de zaal uit, ofschoon zij niet vonden, dat hij zulk een grooten misdaad had bedreven.

Aldus op straat geschopt, liep de mulat als een krankzinnige rond. $\mathrm{Hij}$ wist niet waarheen te gaan en wilde zich de haren uit het hoofd trekken van wanhoop. "Ontslagen ben ik en broodeloos, door een onschuldig geluidje, dat ik zoo heb trachten te bedwingen. $O$, wat een schande! $\mathrm{Tj}$ é, ik wenschte dat grontapoe ben kan opo hem mofo swari mi» (de aarde den mond kon openen om mij te verzwelgen).

Een der beste vrienden van den mulat, die van het voorgevallene gehoord had, zocht den ontslagene op en gaf hem den raad zich onmiddellijk naar den Koning der Verdachte Geluiden te begeven en dezen te vertellen wat er gebeurd was. Deze Koning woonde nog al ver, ergens in een onderaardsch paleis!

De mulat besloot den raad te volgen en ging meteen op weg. $\mathrm{Na}$ een geruimen tijd zoeken kwam hij eindelijk aan het bedoelde paleis. Hij liet zich bij den Koning aandienen, door wien hij zeer vriendelijk ontvangen werd. Deze vernam deelnemend naar al wat de mulat te vertellen had. "Ja, mijn Koning», zoo eindigde de mulat, "die gemeene onderdaan van je heeft mij eerloos ontslag doen krijgen en thans ben ik broodeloos.»

En zou je het bedoelde geluid nog kennen, indien je het nog eens hoorde?» vroeg de Koning hem. De mulat knikte: «ja, mijn Koning.» Toen gebood de Koning al zijn klinkende onderdanen om zich terstond te laten hooren. Onmiddellijk daarna weerklonken de verdachte geluiden ook, eerst de geurlooze, hardere: "prrroo...prroa»... enz., en daarna de riekende, zachtere: "poef...paf»... enz., maar bij elk van deze schudde de mulat ontkennend met het hoofd en sprak: "Neen, dat is het niet.» 
Eindelijk piepte het bekende, zachte: "poewien...»en niet alleen aan den klank, maar ook aan den stank herkende de mulat zijn belager en riep: "dit is de misdadiger."

De Koning zei toen aan den mulat: "Deze onderdaan van mij is de ondeugendste van allen. Hij overvalt fatsoenlijke menschen soms op ongelegen tijden, ook al trachten ze hem te weren. Bovendien dringt hij dan aan iedereen zijn geur op. Ik zal dus zorgen, dat de deugniet het je vergoedt.»

$\mathrm{Nu}$ verplichtte de Koning het poewientje den mulat zooveel goud en zilver uit te keeren als deze voor zijn geheele leven zou noodig hebben. En de mulat keerde een poos daarna met een kar vol schatten huiswaarts. In zijn blijdschap vertelde hij onderweg iedereen, wat een geluk hem overkomen was. Ook $\mathrm{Ba}$ Anansi moest de geschiedenis aanhooren. Deze luisterde aandachtig en besloot ook een poging te wagen om op dezelfde wijze rijk te worden. Met veel moeite gelukte het hem dan ook om een uitnoodiging tot dineeren op het Gouvernement te krijgen.

$\mathrm{Nu}$ had de mulat bij zijn verhaal vergeten te vertellen, door welke der Verdachte Geluiden hij aan de rijkdommen was gekomen en Ba Anansi dacht: "hoe harder geluid, des te grooter rijkdom zal mij dan worden gegeven.»

Toen Ba Anansi op het diner aan tafel was gezeten, deed hij zijn best zoo hard mogelijk zich te doen hooren. Het door hem voortgebrachte geluid klonk ook oorverdoovend: "prrro.... $\mathrm{Na}$ 't hooren van zooiets verschrikkelijks liet de Gouverneur Ba Anansi op de bekende wijze door de schildwachten er uit schoppen. Maar onze vriend jammerde niet, integendeel, hij haastte zich verheugd naar het paleis van den Koning der Verdachte geluiden, waar hij onaangediend binnenstormde. Zonder den Koning zelfs den tijd te gunnen, hem te vragen wat hem was overkomen, ging hij vreeselijk tegen 's Konings onderdanen schelden en dezen van verraad beschuldigen.

"Koning», zoo long hij, "die vuile onderdaan van je heeft mij op het Gouvernement een gemeene poets gespeeld. Ik werd daardoor als een schooier weggejaagd! Ik ben daarom hierheen gekomen om een groote vergoeding van hem te eischen!»

De Koning vroeg toen aan Ba Anansi of hij het misdadige geluid zou herkennen, wanneer hij dit hoorde, waarop Ba Anansi antwoordde: "wel zeker». 
Daarop gebeed de Koning zijn klinkende onderdanen om zich weer in volgorde te doen hooren. Reeds bij de eerste en hardste riep $\mathrm{Ba}$ Anansi uit: " $\mathrm{Hij}$ heeft $\mathrm{mij}$ de kool gestoofd». Maar in plaats dat de Koning nu het "prrro-prrro-a» geluid verplichtte $\mathrm{Ba}$ Anansi te vergoeden, riep hij boos tegen dezen: "Jou gemeene leugenaar, die onderdaan van $\mathrm{mij}$ is een beste jongen en laat zich alleen hooren als men hem daartoe dwingt. Je hebt hem dus er toe gedwongen, geforceerd».

De vorst gaf nu aan al zijn onderdanen bevel om Ba Anansi te tuchtigen. De Verdachte Geluiden gehoorzaamden en sloegen Ba Anansi met hun staarten, dat zijn broek en jas er van scheurden. Maar ten slotte gelukte het den leugenaar toch aan zijn martelaars te ontkomen en vluchtte hij uit vrees voor die stinkende geluiden naar de post'oro, waar hij tot van daag nog woont. Ditmaal kwam Anansi er dus met gescheurde kleeren af.

X. Hoe Ba Anansizijn schuldeischers zonder geld betaalde.

Eer tien tien, Ba Anansi had ongeveer veertig gulden noodig. Om dit bij elkaar te krijgen, leende hij achtereenvolgens van Mat' Kakalakka, Mat' Kakafouloe, Papa Tiegri en Hontiman ${ }^{1}$ ), van ieder tien gulden. Elk van hen nu moest op denzelfden namiddag 't geleende geld bij $\mathrm{Ba}$ Anansi komen terug ontvangen. Echter niet alle op 't zelfde uur. Mat' Kakalakka zou er om 1 uur zijn, Mat' Kakafouloe om 2 uur, Papa Tiegri om 3 uur en Hontiman om 4 uur.

Op den vastgestelden namiddag klopte Mat' Kakalakka ook precies om 1 uur bij Ba Anansi aan. Deze opende terstond de deur en sprak zeer vriendelijk: «Kom binnen, Mat’ Kakalakka, en neem plaats. Ik ben blij je hier te zien, want ik heb het geld voor je klaar gelegd.»

$\mathrm{Ba}$ Anansi legde toen de 10 gulden op tafel. Doch toen Mat' Kakalakka 't geld wou opstrijken om heen te gaan, weêrhield $\mathrm{Ba}$ Anansi hem, zeggende: "Weest niet zoo haastig, Mat' Kakalakka, maar laat dat geld daar even staan. Voor den grooten dienst die je mij hebt bewezen, laat ik mijn vrouw Sa Awense ${ }^{2}$ )

1) Vriend Kakkerlak, vriend Haan, vader Tijger en Jager.

2) Zus inspiratie.

Dl. 80 . 
iets heerlijks voor je klaarmaken. Wacht dus een poosje, het is dadelijk gereed.»

Mat' Kakalakka ging dus maar weer op zijn stoel zitten, zeer verlangend naar de heerlijke verrassing, terwijl Anansi hem intusschen met verhaaltjes bezig hield; totdat de klok 2 uur sloeg en Mat' Kakafouloe aan de deur klopte en vroeg of hij binnen mocht.

Op 't hooren van de stem van zijn vijand schrok Mat' Kakalakka hevig en smeekte $\mathrm{Ba}$ Anansi om hem te verbergen.

- Deze haastte zich Kakalakka naar de keuken te brengen en hem in een diep bord te doen plaats nemen, waarna hij het met een schotel overdekte.

Daarna opende Anansi de deur voor Mat' Kakafouloe en zeide, toen deze kraaiende om zijn geld kwam: "Wat stel jij je aan, Mat' Kakafouloe, men zou denken dat ik je de geheele wereld verschuldigd ben. Denkje soms dat ik je met een paar gulden zal bestelen? Neen, vriendje, 't ligt al klaar voor je. Kijk maar eens.» En Ba Anansi liet Kakafouloe dezelfde tien guldens zien, die hij voor Mat' Kakalakka op tafel had gelegd.

$\mathrm{Nu}$ wou Mat' Kakafouloe zijn geld nemen en weggaan, doch dit voorkwam onze slimme Anansi door te zeggen: "neem het geld nog niet, Mat' Kakafouloe, maar smul eerst eens van wat lekkers, dat ik speciaal voor jou heb bewaard, daar jij mij uit den nood hielp. Kijk in de keuken, daar zul je in een diep bord, dat er staat, wat lekkers toegedekt vinden. Kakafouloe haaste zich er heen, waar hij Mat' Kakalakka dadelijk opslokte. Door dit onthaal goed gestemd, luisterde Kakafouloe met veel genoegen naar Anansi's gebabbel tot het drie uur sloeg en Papa Tiegri, brullend aan de deur klopte. Zoodra Mat' Kakafouloe dit hoorde, begon hij te sidderen van angst. Hij verzocht Ba Anansi een schuilplaats in zijn woning, waartoe deze hem een kist aanwees.

Toen deed de huisbaas voor Papa Tiegri de deur open. Deze kwam woest binnen en eischte zijn geld. Ba Anansi sprak: «Ga bedaard zitten, Papa Tiegri, want de tien guldens liggen al daar op tafel op je te wachten. Kom er echter niet aan, voordat ik je voor je goedheid beloond heb, door je een kleine versnapering aan te bieden. Kijk maar eens in die kist.»

Toen haalde Papa Tiegri Mat' Kakafouloe er uit en at hem heelhuids op. 
Daarna knoopte $\mathrm{Ba}$ Anansi met schuldeischer $\mathrm{N}^{\circ} .3$ een praatje aan, dat niet lang behoefde te duren, want weldra zou Hontiman aan de deur zijn.

Toen deze ook aanklopte, vroeg Papa Tiegri, uit vrees voor Hontiman, aan Ba Anansi, waar hij zich verbergen kon.

Daarop gaf $\mathrm{Ba}$ Anansi hem den raad om op een tak in een boom bij het huis te klimmen.

Vlug sprong Papa Tiegri toen een zijraam uit, beklom den boom en strekte zich op den aangewezen tak uit, waarna $\mathrm{Ba}$ Anansi aan den nieuwen bezoeker toegang verleende.

Deze eischte terstond zijn geld van Ba Anansi terug, die kalm antwoordde geen geld maar iets beters te hebben.

Hontiman moest maar eens in het watervat naast het huis kijken.

Dit deed de laatste ook en zag door het water Papa Tiegri's beeld weerspiegeld.

Meteen richtte hij zijn geweer omhoog, mikte, schoot en Papa Tiegri viel doodelijk getroffen met een plof neer.

Daar Tiegri's huid Hontiman meer waard was dan het uitgeleende geld, behoefde $\mathrm{Ba}$ Anansi dit niet terug te betalen, ook mocht hij Papa Tiegri's vleesch hebben, waarvoor hij Hontiman bij diens vertrek hartelijk bedankte.

En zoo betaalde de slimme Ba Anansi zijn schulden zonder geld.

$$
\text { XI. A-friengi. }
$$

(Smijter).

Eer tien tien, Er heerschte groote hongersnood en iedereen leed gebrek. Ook $\mathrm{Ba}$ Anansi had niets te eten en dwaalde hongerig rond, zoekende naar voedsel. - Eindelijk diep in het bosch gekomen, ontdekte hij een enorm grooten steen met een verbazend langen baard. Ten zeerste verwonderd riep hij uit: "Mijn God, dat is voor het eerst in mijn leven, dat ik een steen zie met een baroeba (baard)!» Doch nauwelijks had Ba Anansi het woord «baroeba» geuit, of de steen, een a-friengi, wentelde zich om en sloeg hem op zoo'n wijze, dat hij een heel eind de lucht in vloog. Gelukkig kwam Anansi weer zonder letsel op zijn beenen terecht. - Deze gebeurtenis bracht $\mathrm{Ba}$ Anansi op de gedachte om van dezen wondersteen voordeel te trekken. Hij maakte ter plaatse waar hij terecht gekomen was een kruis en plaatste in het midden hiervan een scherp toegespitste 
staaf, met de punt naar boven gekeerd. Daarna ging Ba Anansi de dieren uit den omtrek naar de gevaarlijke plaats lokken. Hij begon met $\mathrm{Pa}$ Tiegri, Omoe Bofroe, Mat' $\mathrm{Dia}^{1}$ ) er heen te gaan, tot elk hunner zeggende: "Kom mee en ik zal je een steen met een baard wijzen. Deze steen is de tata (vader) van het bosch hier, waarom een ieder die hem nadert moet uitroepen: «mijn God, dit is voor het eerst in mijn leven, dat ik een steen zie met een ba roeba! Wie dit niet doet, sterft binnen korten tijd een vreeselijken dood".

Telkens als een van deze dieren het woord ba roeba uitte, wierp de a-friengi den ongelukkige omhoog. Deze viel dan op de puntige staaf, die hem geheel doorpriemde, zoodat hij een prooi van den listigen $\mathrm{Ba}$ Anansi werd.

Ba Anansi kwam ook zijn Mat' Sjen sjen ${ }^{2}$ ) tegen, dien hij eveneens meenam om den steen met een baard te zien. Onderweg echter vergat $\mathrm{Ba}$ Anansi aan Mat' Sjen sjen mede te deelen, wat deze moest uitroepen. In de nabijheid van de a-friengi gekomen, wilde $\mathrm{Ba}$ Anansi dit nog doen en sprak zachtjes: "Mat' Sjen sjen, als je niet wil dat de boesi tata (boschvader) je spoedig op een akelige manier laat omkomen, roep dan uit: "Mijn God, dit is voor het eerst in mijn leven, dat ik een steen zie met een ba ...ba ...ba ...!» Waarop Mat' Sjen sjen het woordelijk na zei: "Mijn God, dit is voor het eerst in mijn leven dat ik een steen zie met een ba... ba... ba...!»

"Neen», riep Ba Anansi, "dat is niet goed, je moet zeggen: "Mijn God, dit is voor het eerst in mijn leven dat ik een steen zie met een baroe... roe... roe!» Weder sprak Mat' Sjen sjen $\mathrm{Ba}$ Anansi's woorden precies na: "Mijn God, dit is voor het eerst in mijn leven, dat ik een steen met een baroe... roe... roe!» Toen werd Ba Anansi ongeduldig en riep uit: «Wees toch zoo dom niet, Mat' Sjen sjen, maar zeg: Mijn God, dit is voor het eerst in mijn leven, dat ik een steen zie met een ba roeba!»

En nauwelijks was het verboden woord «baroeba», Ba Anansi's lippen ontglipt of de a-friengi wierp hem de lucht in.

Angstig schreeuwde $\mathrm{Ba}$ Anansi bij het neerkomen zijn vrouw toe: "Sa Akoeba, ò, poeroe pennitji, na Anansisrefi

1) Papa Tijger, Oom Tapir, Vriend Hert.

z) Vriend Houtworm. 
de kom» (Zus Akoeba, neem den staaf weg, 't is spin zelf, die komt!)

Doch de goede vrouw was daar niet aanwezig, dus onderging Ba Anansi hetzelfde lot als zijn slachtoffers. En zoo trof Sa Akoeba haar echtgenoot iets later aan, gevangen in zijn eigen val. Voorzichtig bevrijdde zij hem en met veel moeite gelukte het haar eindelijk de wonde, die hij bekomen had, te genezen.

Het litteeken echter bleef aan zijn borst. En zoo is de kleine holte ontstaan, die iedere spin aan de onderzijde van haar lichaam bezit.

Mat' Sjen sjen, die getuige van het gebeurde was geweest, riep de andere dieren van het bosch bijeen en vertelde hun hoe hij door een toeval aan den dood ontkomen was. Alle scholden Anansi voor een valschaard en riepen: "Wie een kuil voor anderen graaft, loopt gevaar er zelf in te vallen».

\section{Tangi fo boen na kodja.}

(Dank voor het goede is de knots: stank voor dank).

Eer tien tien, Ba Anansi bezocht Mat' Sjen sjen, die bezig was, verschillende vleeschgerechten te bereiden. Hij zoutte, peperde, berookte, kookte, braadde en stoofde. Ba Anansi watertandde bij dit alles en vroeg: "Mi mama, ${ }^{1}$ ) Mat' Sjen sjen, waar heb je zoo'n massa vleesch vandaan gekregen?» Mat' Sjen sjen wou hem dit niet zeggen, want hij dacht: "efi a kaba na patoe, a kaba na spoen toe, "als het in de pot op is, dan is het in den lepel ook op», d. w. z. als de bron uitgeput geraakt, houden de middelen ook op. Doch Ba Anansi mocht een hapje mee eten. Onder het eten echter smeekte Ba Anansi Mat' Sjen sjen om toch medelijden met hem te hebben en hem te vertellen, waar hij toch al dat vleesch vandaan haalde. Wel, zei Mat' Sjen sjen, als ik vleesch noodig heb, neem ik mijn mes en korf en ga naar den stal van den Koning, waar Sa Hauw (Zus Koe) woont, die een groote lachbek is. Daar gekomen kittel ik Sa Kauw, die dan met wijdgeopenden bek begint te lachen, hetgeen een paar uren duurt.

Ik loop dan door den open bek van Sa Kauw tot naar binnen en snijd er zooveel vleesch uit haar buik, als ik meenemen kan.» Nadat Ba Anansi de geheele geschiedenis gehoord had, ver-

1) Uitroep van verbazing. 
zocht hij aan Mat' Sjen sjen hem op den eerstvolgenden vleeschroof mede te nemen, waarin de goedhartige vriend toestemde.

Op den vastgestelden dag begaven Ba Anansi en Mat' Sjen sjen zich met hun messen en korven naar den stal des Konings. Mat Sjen sjen kittelde Sa Kauw, die ook den bek opende, om een geruimen tijd te lachen. Terstond gingen de beide vleeschroovers door den open bek van Sa Kauw en kwamen zoo in haar buik. Reeds hadden zij daar bijna hun korven vol vleesch gesneden, toen Ba Anansi de onhandigheid beging om Sa Kauw een levensader door te snijden. Hij bemerkte dit echter bijtijds en kroop, toen Sa Kauw den laatsten adem uitblies, met zijn korf haar bek uit, welke achter hem dicht viel, waardoor Mat' Sjen sjen in den buik der doode Sa Kauw gevangen bleef.

Kort daarop heerschte er in het paleis groote ontsteltenis. Sa Kauw, de beste koe van den Koning, was plotseling gestorven en daar de oorzaak niet bekend was, wou de Koning haar lijk in de rivier doen werpen. Maar Ba Anansi voorkwam dit met te zeggen: "Laat Sa Kauw's lichaam niet zonder onderzoek weggooien, mijn Koning. Immers Sa Kauw was niet ziek en de dood moet een oorzaak hebben. $\mathrm{Zij}$ is dus vermoord en als gij mij haar vleesch en wat geld er bij wilt geven, zal ik den moordenaar aanwijzen.» De Koning vond dit goed en Ba Anansi sneed terstond het vermoorde dier den buik open. Hij zou zoodra Mat' Sjen sjen te voorschijn mocht komen dezen dooden en het lijk aan den Koning brengen. Maar dit ging zoo makkelijk niet, daar Mat' Sjen sjen zich tot in de darmen had verborgen, waar $\mathrm{Ba}$ Anansi hem na voelen en tasten ontdekte.

Ba Anansi nam toen een knots en sloeg de darmen plat. Met het oor tegen deze aangedrukt sprak hij toen: "tjè, als Sjen sjen er nog was, zou hij zeker zijn aandeel van het vleesch krijgen.» Mat' Sjen sjen riep toen met zwakke stem: «ik ben er nog, Ba Anansi, ik ben er nog.,

Dit hoorende, hamerde $\mathrm{Ba}$ Anansi wel tweemaal zoo hard op de darmen, waarna hij weer luisterde en luid riep: " $t \mathrm{jè}$, als Mat' Sjen sjen er nog was, zou hij zeker zijn aandeel van het vleesch krijgen.» Daarop klonk Mat' Sjen sjen's stem veel zwakkker dan den eersten keer: "ik ben er nog, Ba Anansi, ik ben er nog.»

$\mathrm{Ba}$ Anansi sloeg nu andermaal met verdubbelde kracht de darmen plat en plaatste er voor de derde keer zijn oor tegen, terwijl hij schreeuwde: "tjè, als Mat' Sjen sjen er nog was, 
zou hij zeker zijn aandeel van het vleesch krijgen, maar hierop zweeg Mat' Sjen sjen. Hij was doodgeslagen. Zeker zijnde, dat Mat' Sjen sjen niet meer tot de levenden behoorde, opende Ba Anansi de darmen met zijn mes en toonde aan den Koning Mat' Sjen sjen's lijk: 'Ziehier den moordenaar van uw koe, mijn Koning». De Koning, die meende, dat er recht geschied was, keerde de beloofde premie aan Ba Anansi uit, die met Sa Kauw's vleesch een groot feest gaf. De verhaler van deze Anansitori, die ook gevraagd werd op het maal, moest toch bij het naar huis gaan even denken aan den armen Sjen sjen. "Ja, dacht hij, van je vrienden moet je het hebben.»

XIII. No wan Soema, dé naki makoe fo lau. (Niemand slaat makoe's [groote muskietsoort] voor de malligheid).

Eer tien tien, Mat' Kesikesi klaagde voor Ba Anansi, dat hij geen vet had, om zijn spijzen te bereiden, waarop Ba Anansi zeide: "Luister, Mat' Kesikesi, ik breng je dadelijk naar Gramman Assau's (Gouverneur Olifant) verblijfplaats in het bosch. Daar maak je voor Gramman Assau een paar vermakelijke buitelingen en hij zal den bek openen en lachen. Daar bij het lachen zijn anus ook open gaat, kun je hierdoor tot in zijn buik loopen, waar je zooveel vet neemt, als je noodig hebt. Als je b.v. een emmer vol hebt, kom je weer uit Gramman Assau's buik. Wat zeg je er van, ehn, Mat' Kesikesi?» Mat' Kesikesi vond het uitstekend en nam vol blijdschap Ba Anansi's voorstel aan. Samen zouden zij Gramman Assau opzoeken. Onderweg echter zeide Ba Anansi: "Maar zie je, Mat' Kesikesi, waar ik je aan vet help, moet jij ook wat werk voor mij doen, terwijl ik buiten de wacht houd.» Mat' Kesikesi die geen kwaad vermoedde, vond dit goed. Doch Anansi indachtig aan de odo (spreekwoord), no wan soema dé naki makoe foe lau, d.w.z. niemand werkt voor niemendal, had heel wat anders in den zin. Het was niet uit welmeenendheid of om zich een beetje werk te besparen, dat hij Mat' Kesikesi van dienst wou zijn. De schurk had n.l. in den laatsten tijd verbazend veel vet van Gramman Assau geroofd, en vreesde dat deze ten gevolge daarvan zou bezwijken, als hij het weer eens zou wagen. Tevens wist Ba Anansi, dat Mat' Kesikesi te erg stotterde om hem in geval van nood te kunnen verraden. Daarom vertrouwde Ba Anansi 
zonder aarzelen het belangrijke vetgeheim aan Mat' Kesikesi toe.

Op het erf van Gramman Assau gekomen, buitelde Mat' Kesikesi ook verscheiden malen over den kop, hetgeen de groote Assau werkelijk den bek deed openen om luid en lang te lachen. En werkelijk stond hierbij zijn anus wijd open.

Onmiddellijk wipte Mat' Kesikesi met twee emmers in de geopende anus, door welke hij Gramman Assau's buik binnen trad. Vlug vulde hij daar een emmer met vet en bracht dezen, volgens afspraak voor Ba Anansi buiten.

Toen keerde hij terug en begon zijn tweeden emmer met vet te vullen. De reeds uitgeputte Gramman Assau deed echter den bek toe, waardoor de Anus zich ook sloot. Hij stortte ineen en gaf den geest. Mat' Kesikesi kon onmogelijk weer uit het doode lichaam van Assau komen, terwijl Ba Anansi vrij naar huis ging om zijn buit te verbergen.

Gramman Assau's overlijden bracht groote ontsteltenis teweeg in het geheele land. Men had wel gezien dat Gramman Assau erg vermagerd was, maar toch had men zijn dood niet verwacht. En daarom zou de Koning graag de doodsoorzaak willen weten. $\mathrm{Op}$ het vernemen hiervan verklaarde $\mathrm{Ba}$ Anansi terstond, dat men Gramman Assau vermoord had en dat hij den moordenaar aan het gerecht zou kunnen overleveren, wanneer de Koning hem hiervoor Gramman Assau's lichaam wou afstaan.

Het aanbod werd aangenomen. Ba Anansi sneed Gramman Assau's lijk open, waaruit Mat' Kesikesi met zijn emmer half vol vet voor den dag kwam. Ba Anansi riep toen: «Hier heb je den moordenaar, mijn Koning.»

$\mathrm{Nu}$ wou Mat' Kesikesi den lagen Ba Anansi ontmaskeren en vertellen wat er gebeurd was, doch hij kon slechts stotteren: «jai-ti ko ko ko!»

De Koning gaf dus den dooden Assau aan Ba Anansi ter belooning en liet Mat' Kesikesi voor straf levenslang in een kooi opsluiten. Daarom houdt men nog altijd apen in kooien om zich met hun malle buitelingen en stotterend piti ko ko ko te vermaken.

XIV. Kaptein don'si fajer.

(Kapitein ziet liever geen vuur).

Eer tien tien, Ba Anansi kreeg van zijn vriend, den scheepskapitein, eenige versleten zeemanskleeren, o, a, een paar oude 
schoenen en een gedeukten hoed. $\mathrm{Nu}$ hadden deze prullen eigenlijk geen -waarde, maar Ba Anansi borg ze verheugd weg, daar hij er zijn vrouw Sa Akoeba mee voor den gek wou houden, teneinde wat lekker eten yan haar te krijgen.

Thuisgekomen vertelde $\mathrm{Ba}$ Anansi dien middag aan zijn goedige vrouw, dat een van zijn oude kennissen, een zeekapitein, haar tegen den avond zou bezoeken. De man kwam Sa Akoeba spreken, over haar oudsten zoon, dien hij tot kapitein wenschte op te leiden. $\mathrm{Zij}$ moest hem dus zoo gul mogelijk ontvangen, om hem des te gunstiger voor hun zoon te stemmen.

Verheugd over de goede vooruitzichten van haar kind, maakte Sa Akoeba terstond alles onder $\mathrm{Ba}$ Anansi's toezicht gereed voor een kostelijk onthaal. $\mathrm{Zij}$ slachtte haar vetsten kalkoen en kocht met haar spaarpenningen andere lekkernijen o. m. dranken, waarvan zeelui gewoonlijk veel houden.

Toen de boel dan eindelijk klaar gezet was, loog Ba Anansi, dat hij den kapitein van boord moest halen, waarop hij heenging.

Even later werd aan de deur geklopt en iemand vroeg met grove stem, of hij binnen mocht. Sa Akoeba deed open. De kapitein trad alleen binnen, groette en vroeg in slecht Engelsch of $\mathrm{Ba}$ Anansi niet kwam.

Sa Akoeba gaf hierop ten antwoord dat haar echtgenoot den kapitein was gaan afhalen en deze gemist moest hebben. Hij zou wel straks terug zijn. De kapitein wou echter overjas nòch hoed afdoen. Ook mocht de lamp niet aangestoken worden, hoewel de schemering reeds inviel, - daar de kapitein zeide: "no, no, kaptin don'si fajer, bikas fajer brok'mi ai, sinsimi ben de wan little bois (nu, nu, kapitein ziet liever geen vuur, want vuur brak mijn oog, sedert ik een kleine jongen was).

Sa Akoeba bood den zeeman toen een stoel aan, op welken hij zich zonder verdere plichtplegingen neerzette en meteen over Sa Akoeba's zoon begon te spreken. Hij wou den jongen het kapiteinsvak leeren. Ba Anansi had er niets tegen. Maar nu wou hij weten of Sa Akoeba bang was, hem het kind toe te vertrouwen. Sa Akoeba antwoordde, dat het haar juist een groot genoegen was, dat de kapitein den knaap bij zich aan boord wilde nemen. Het was een flinke jongen, die zeker zijn best zou doen. De kapitein verzekerde haar dit met blijdschap te vernemen.

Hij kon echter den knaap eerst de volgende reis meenemen. $\mathrm{Hij}$ zou Sa Akoeba wel kunnen zeggen waarom dat nu nog 
niet ging maar zij zou het toch niet begrijpen, daar zij geen verstand van zeezaken had.

Natuurlijk moest Sa Akoeba hiermee genoegen nemen. $\mathrm{Zij}$ meende nu den kapitein ten eten te moeten vragen, welke uitnoodiging direct aangenomen werd.

De kapitein zou echter liever niets gebruiken zoolang Ba Anansi er nog niet was.

Herhaaldelijk sprak hij tot zijn aanstaanden scheepsleerling: « Mi want fo si joer fada. (Ik wil uw vader zien). Boiwer joer fadas (waar is uw vader)?

Deze antwoordde telkens dat zijn vader den kapitein van boord was gaan halen en zeker dadelijk weer thuis zou komen.

Doch Ba Anansi kwam maar niet terug, waarom Sa Akoeba bij den zeerob er op aandrong om toch aan tafel te gaan daar het eten anders koud zou worden.

De kapitein nam toen aan de tafel plaats en begon daar in de schemering gulzig van de lekkere spijzen te eten. Hierbij smakte hij met de lippen, op dezelfde wijze als Anansi dat gewoon was, waarom de jongste zoon de zaak een beetje begon te wantrouwen. Ook vergiste hij zich bij het spreken af en toe en meende de jongen zijn vaders stem te herkennen.

$\mathrm{Om}$ nu zekerheid te krijgen, kroop de knaap ongemerkt onder de tafel en streek er zachtjes een lucifer aan. Toen lichtte hij even de broekspijp van den kapitein op en riep terwijl hij hem aan de dunne beenen greep: $\mathrm{Ma}$, ma, het is niets geen scheepskapitein, het is mijn papa zelf!»

Op het hooren hiervan pakte Sa Akoeba haar vermomden echtgenoot beet, rukte hem overjas en hoed af, terwijl een der kinderen de lamp aanstak.

En daar stond nu Ba Anansi ontmaskerd en smeekte om vergiffenis. Doch Sa Akoeba in haar woede, wou van geen vergiffenis weten. $\mathrm{Zij}$ nam een stok en begon Ba Anansi onbarmhartig te ranselen. Eerst nadat ze hem half dood geslagen had, gelukte het Anansi aan de handen zijner driftige vrouw te ontkomen en naar de post'oro te vluchten, waar hij sedert woont. En daarom weigert de spin ook alle voedsel wanneer men haar dit aan een stokje toesteekt met de woorden: "Ba Anansi, het is voor jou en je vrouw». Zegt men echter "Ba Anansi het is voor jou alleen, dan grijpt hij dadelijk toe en brengt het snel naar de post'oro, 
XV. Na san dé wan soema doe joe, na dati joe moesoe doe hem bakka.

(Hetgeen iemand je gedaan heeft, dat moet je hem weer doen).

Eertien tien, Ba Anansi en Ma Todo (Moeder Kikvorsch) zouden op een diner naast elkaar aan tafel zitten en dus ieder een bord voor zich krijgen. De gulzige $\mathrm{Ba}$ Anansi wilde van beide borden eten, en zeide daarom tot Ma Todo, toen deze kwam zitten: "sja ${ }^{1}$ ), Ma Todo, wat zijn je handen vuil! Wasch ze gauw schoon, eer je met eten begint, want niemand komt met zulke vuile handen aan tafel.» Ma Todo stond toen op en ging de handen wasschen achter het huis, waar er een vat water stond. Ba Anansi maakte van Todo's afwezigheid vlug gebruik om een paar hapjes uit haar bord te nemen. Daar echter Ma Todo niet anders dan springende, met de handen op den grond, weer de tafel kon bereiken, waren deze even vuil als van te voren, toen zij weer op haar stoel zat. Wederom merkte $\mathrm{Ba}$ Anansi op: «Hm, Ma Todo, je handen zijn nog even vuil! Wasch die toch eerst goed schoon, voordat je met eten begint, anders zal je besproken worden.» Zoo wist Ba Anansi Ma Todo telkens weer weg te krijgen en smulde dan uit Ma Todo's bord, tot groot vermaak der overige gasten.

Het diner liep af en Ma Todo had nog van al de lekkere spijzen geen hapje geproefd. Toen zij daarover pruttelde, raadde Ba Anansi haar aan, om de beentjes af te kluiven, die onder de tafel gevallen waren. Doch Ma Todo was zeer boos en zou zich wel wreken.

Eenige dagen later gaf $\mathrm{zij}$ een eetpartij onder water, en noodigde niet alleen de dieren die aldaar woonden uit, maar ook Ba Anansi.

Deze trachtte ook op den bepaalden dag Ma Todo's huis op den bodem van het water te bereiken maar kon niet zinken bij gebrek aan gewicht. Drijvend op het water, bedacht Ba Anansi een middel om toch op de partij te komen.

Fluks zwom hij naar den oever, waar hij van zijn vriend, den lijkdrager, een lange zwarte jas leende. Dit kleedingstuk trok Ba Anansi aan en vulde daarna de zakken met zware steenen. Vervolgens verzocht hij een plantagebewoner om in diens boot mee te varen, hetgeen hem toegestaan werd. Midden in de

1) Uitroep van viesheid. 
rivier echter verklaarde $\mathrm{Ba}$ Anansi, dat hij wilde uitstappen en deed dit ook, niettegenstaande de plantageman hem voor verdrinken waarschuwde.

Bezwaard door zijn met steenen beladen jas, zonk Ba Anansi naar de diepte en kwam zoo tot aller verwondering op het feestmaal aan, juist toen men aan tafel zou gaan.

Toen Ba Anansi in zijn zwart pakje wou plaats nemen, weerhield Ma Todo hem, zeggende: "Neen, Ba Anansi, met zoo'n lang Tiengi fowloe djakti (stinkvogel-jas) gaat men wel begraven, maar komt men niet aan tafel. Doe je koti (gekleede jas) dus eerst af, voordat je eet.» En of Anansi wou of niet, hij moest gehoorzamen. Nauwelijks had echter Ba Anansi den met steenen bezwaarden jas uitgetrokken, of hij steeg spartelend weer naar de wateroppervlakte. De andere gasten, die dit zagen, lachten hem hartelijk uit. En toen $\mathrm{Ba}$ Anansi zich luidkeels beklaagde, schreeuwde Ma Todo hem toe, dat hij het vet, dat boven water kwam drijven, maar moest aflikken.

Toen wendde Ma Todo zich tot de aanwezigen en vertelde hun, wat $\mathrm{Ba}$ Anansi haar op die andere partij geleverd had. «En zie je», zoo eindigde zij, ik heb gedacht «leer om leer, ik zal je ook wel te pakken krijgen».

\section{Tjari faja. \\ (Verdraag vuur).}

Eer tien tien, Ba Anansi ging met Mat' Fouloe (vriend kip) een weddenschap aan, wie van beiden een grootere hitte zou kunnen verdragen. Daartoe plaatsten zij twee potten op 't vuur, één met olie en één met water. Ba Anansi sprong dadelijk in den pot met olie, op welken Mat' Fouloe terstond het deksel plaatste. Daarna klom Mat' Fouloe in den pot met water en liet zelf het deksel er op vallen. Toen Ba Anansi zeker was, dat Mat' Fouloe in den pot zat, kwam hij stilletjes uit zijn pot en zette zachtjes twee zware steenen op het deksel van Mat' Fouloe's pot neer. Hij ging toen naast den pot met olie staan en wachtte af wat er gebeuren zou. $\mathrm{Na}$ een poosje zuchtte Mat' Foulie: "a $\mathrm{mm}^{1}$ ), Ba Anansi, ik stik haast van de warmte, waarop Anansi haar aanmoedigde: «tjar' faja, tjar' faja, Mat' Fouloe, anders zul je de weddenschap verliezen, want ik kan 't hier nog best een tijdje uithouden.» Nu wou Mat' Fouloe niet

\footnotetext{
1) Diepe zucht.
} 
graag verliezen en hield zich dus nog eenige oogenblikken dapper. Maar kort daarop begon zij te kermen: "oi, o i, ik kom er uit, Ba Anansi! Het water brandt mij al, ik kan niet meer.» Nou sprak Ba Anansi: "doe dat en geef mij het lekkers, waarom wij gewed hebben, want ik heb eerlijk gewonnen.» Maar toen Mat' Fouloe het deksel wou lichten, ging dit door de steenen niet. Uit angst begon Mat' Fouloe te schreeuwen: ‘kom mij gauw helpen, Anansi, ik kan het deksel niet van den pot krijgen,» waarop $\mathrm{Ba}$ Anansi antwoordde: «ik kan mijn pot ook niet open krijgen.»

Op het hooren daarvan gilde Mat' Fouloe het uit: «wai, $\mathrm{wa}^{1}{ }^{1}$ ) ik word hier levend gekookt!» Maar Anansi stoorde zich niet aan het gejammer en wachtte bedaard tot het stil in den pot werd. Toen opende hij dezen en haalde de gekookte Mat' Fouloe er uit, die hij nu in den pot met olie deed om bruin te braden. Zoo wist de slimme Anansi dien middag een fijn kippenboutje te hebben bij zijn gewoon maal van "groene bananen.

XVII. Hoe Ba Anansi zijn schuldeischerseen poets speelde.

Eer tien tien, Ba Anansi had van vele zijner bekenden geld geleend en kwam nu op alle hoeken der straten schuldeischers tegen, die hem brutaal om geld vroegen. Een hunner, Papa Tiegri, van wien $\mathrm{Ba}$ Anansi het meeste geld had, dreigde hem vaak, dat als hij hem niet betaalde, hij er toe zou overgaan, Anansi te vermoorden. En alleen Ba Anansi's slimheid redde hem gewoonlijk uit de handen der politie en van den dood. $\mathrm{Ba}$ Anansi had intusschen geen rust. Hij besloot daarom de lastige schuldeischers op een behoorlijken afstand te houden, en stak zich zonder dralen in de huid van een assau (olifant). Daar dit vel hem veel te wijd was, hing het slap om zijn lichaam en geleek hij precies op een vermagerden zieken assau.

Zoo vermomd ging Anansi de straat op teneinde door zijn schuldeischers voor "Granpapa Assau» (Grootvader Olifant) aangezien te worden, wien allen belangstellend naar zijn gezondheid zouden vragen. Wat Anansi had verwacht, gebeurde ook. De schuldeischers begroetten hem als Granpapa Assau en vroegen, wat er aan scheelde. "Wel, zeide de magere assau; «ik leende $\mathrm{Ba}$ Anansi geld en toen ik het van hem terug eischte,

1) Pijnlijk gegil. 
wilde hij 't me niet geven. Ik dreigde hem toen te zullen dooden, waarop hij zijn wisi (toovermiddel) op mij spuwde.

Sedert dien dag ben ik niet meer dezelfde. Ik wou wel dat ik dien Anansi nooit het geld had teruggevraagd.. Op het hooren daarvan schrokken de schuldeischers, waaronder ook Papa Tiegri en vroegen Anansi nooit weer naar geld. Integendeel, toen de schuldenaar hem riep om het geld te komen halen, antwoordden zij: "ach laat maar, 't is goed zoo». En Ba Anansi had daar natuurlijk geen bezwaren tegen.

\section{Hoe Mat' Marbonsoe (vriend wesp) aan een dun middellijf kwam.}

Eer tien tien, Mat' Marbonsoe was eertijds dikbuikig. Eens vroeg $\mathrm{Ba}$ Anansi hem om mee te gaan visschen en vertelde hem o. $\mathrm{m}$. het volgende: "als je die warrapa's (vischsoort) van dat vischgat ziet, waar ik je brengen zal, Mat' Marbonsoe, je gelooft het vast niet, maar ze zijn wel zoo dik als mijn bout». Hierop barstte Marbonsoe in een onbedaarlijk lachen uit, waardoor zijn buik (middellijf) zeer dun werd en tot vandaag nog dun is gebleven. Als men nu nagaat, hoe dun de pooten van een spin zijn, dan kan Mat' Marbonsoe's gelach geen verwondering wekken. In Suriname heeten dunne dijen anansibouten.

XIX. Gangan (Grootje) Clementia's uitroep.

Eerotien tien, Er was eens een oud moedertje dat haar naam zoo strikt geheim wist te houden, dat niemand dien kende. Iedereen noemde haar daarom "gangan». De Koning, die zeer nieuwsgierig was, beloofde heel wat schatten aan dengene, die hem den naam van gangan zou weten te zeggen. Ba Anansi, die de schatten best kon gebruiken, bedacht allerlei middeltjes, om achter den verborgen naam te komen. Hij wist dat oude negers gewoon waren om bij het «Gatto plessi mi», 't welk zij uitroepen, wanneer iets hen ten hoogste verbaast, ook hun eigen naam te voegen. En deze uitroep van verbazing zou hij aan de lippen der gangan trachten te ontlokken.

Tot dit doel verkleinde $\mathrm{Ba}$ Anansi zich met obia (zwarte kunst), maar liet de haren op 't lichaam staan en de geslachtsdeelen ook zoo groot als zij waren. Hij geleek dus op een pas geboren kind, maar met de geslachtsdeelen van een volwassen man. Na deze gedaanteverwisseling verzocht hij zijn vrouw Sa 
(Zus) Kwasiba hem als een echte baby in te bakeren en zoo naar de gangan te brengen. Aan deze moest Sa Kwasiba vragen het wichtje een paar uurtjes voor haar te houden, daar zij wat werk in den kostgrond te verrichten had. $\mathrm{Zij}$ zou het zelf wel komen terughalen. Maar de gangan moest vooral zorg dragen het kindje een schoone luier te geven, in het geval het zich nat makte, waar veel kans op was. Sa Kwasiba deed ook precies wat Anansi wenschte. Na de verkleinde Anansi als een baby te hebben verkleed, ging zij naar de gangan en verzocht deze, het kindje zoolang voor haar te houden. De goedhartige ga ng a n deed dit gaarne. Daarbij reikte Sa Kwasiba haar het kind en de reserve luiers toe, zeggende: "als baby een luier mocht noodig hebben, dan heb je hier wel genoeg schoone». Hierna ging zij heen. Nauwelijks was Sa Kwasiba weg, of de kleine Anansi begon uit alle macht te schreeuwen. Gangan begreep, dat het kindje iets gedaan had en sprak sussend: «aji, aji, (ja, ja,) je hebt zeker je luier vuil gemaakt, nietwaar?» er met een tiengi-noso (opgetrokken neus) bijvoegende: «hm, maar voor zoo'n jong kind stinkt dat toch veel te veel hoor!» Gan g a n plaatste den kleinen Anansi op haar schoot en maakte de luier los. Maar nauwelijks was die er af, of zij sloeg van verbazing de handen ineen en riep, gelijk $\mathrm{Ba}$ Anansi gehoopt had: Gat to plessi mi, Clementia, na njoen njoen pikien, tan so» (God zegen mij, Clementia, ziet een pasgeboren kind er zoo uit)? En hoofdschuddend bond de gangan het kindje de schoone luier aan, waarna zij het in een hoek harer kamer neerlegde. Zulk een man-kind wou gangan niet langer in haar armen sussen. Gelukkig hoefde dat ook niet, daar de kleine Anansi zoet bleef, totdat Sa Kwasiba kwam. Toen deze Ba Anansi weer meenam, fluisterde hij haar toe: "a sani pieki» (Het ding heeft beantwoord).

Thuisgekomen herkreeg Ba Anansi weer zijn gewone gedaante, deed zijn Zondagsche pakje aan en ging direct naar den Koning, tot wien hij met een diepe buiging sprak:

Ik ben gekomen, mijn Koning, om je den naam der ganga n te zeggen». De koning vroeg hem hierop hoe die was, en Ba Anansi sprak luid: "die gangan heet Clementia».

Terstond ontbood de koning de gangan om haar te vragen, of hetgeen $\mathrm{Ba}$ Anansi gezegd had, waarheid was en zij werkelijk Clementia heette. De ga n ga n moest dit vol verbazing erkennen. 
De Koning liet de gangan gaan en vroeg toen aan Ba Anansi, hoe deze toch den naam van dat oud moedertje te weten was gekomen, waarop $\mathrm{Ba}$ Anansi hem de geheele geschiedenis vertelde. De Koning telde Ba Anansi de beloofde schatten voor, terwijl hij lachende zei:

«Ba Anansi, ma joe dé wan bredde!», (maar je bent een stukje brood).

XX. Miesi (juffrouw) Wilhemsi's geheim.

Eer tien tien, Er was eens een rijke vrouw, wier naam aan niemand anders bekend was dan aan haar vertrouwde bediende. En deze zou zich liever de tong uit de keel laten trekken, dan het geheim van haar meesteres opzettelijk verraden.

$\mathrm{Nu}$ wou de rijke vrouw niet anders trouwen, dan met den man, die wist hoe zij heette, en natuurlijk was dat oorzaak, waarom de dwaze vrouw ongehuwd bleef. Ba Anansi, wetende welke groote schatten deze vrouw bezat, zou wel met haar willen trouwen, en stelde een onderzoek in naar haar naam.

Het was bekend, dat meiden de gewoonte hadden om bij al het moeilijke werk dat zij verrichten, bij zichzelf te pruttelen tegen hare werkgeefster of meesteres.

Daarom beklom Anansi een boom vlak naast den put, waar de bediende der rijke vrouw elken dag water kwam halen. En daar genoemde put op een tamelijk grooten afstand van het huis harer miesi was, mopperde de vertrouwde bediende, toen zij er als gewoonlijk, op het bepaalde uur water kwam putten, zóó duidelijk, dat $\mathrm{Ba}$ Anansi elk woord kon verstaan: "O, ik weet niet waarom Miesi Wilhemsi juist mij elken dag zoover moet sturen om water te dragen. Dat grapje begint mij nu te vervelen, 't is toch een feit, dat als je lang bij die miesis in dienst bent, ze je net als een slaaf behandelen.»

Toen de meid weg was, kwam Ba Anansi, die den naam der rijke vrouw gehoord had, naar omlaag, begaf zich direct naar huis, nam er zijn guitaar en ging Miesi Wilhemsi een serenade brengen. Onder Miesi Wilhemsi's balkon gekomen, zong $\mathrm{Ba}$ Anansi daar luidkeels met begeleiding van de guitaar: «Miesi Wilhemsi, Goedoe-goedoe oema! Goedoe-goedoe oema, Miesi Wilhemsi!» (Juffrouw Wilhemsi, lieve vrouw)!

Op het hooren van dit liedje zond Miesi Wilhemsi haar bediende om $\mathrm{Ba}$ Anansi binnen te roepen. $\mathrm{Zij}$ vroeg toen, hoe 
hij haar naam te weten gekomen was, maar Ba Anansi wilde haar dat niet zeggen. De vrouw moest nu haar woord houden en met hem trouwen. Spoedig daarna werd dan ook de bruiloft gevierd. Doch na het huwelijk moest $\mathrm{Ba}$ Anansi telkens zeven trappen beklimmen, om in Miesi Wilhemsi's kamer te komen, daar deze zich op de zevende verdieping van het groote huis bevond. Anansi klaagde vaak dat dit geklim en geklauter hem pijn op de borst gaf. Als Miesi Wilhemsi haar intrek op de eerste verdieping wilde nemen, zou het veel beter zijn. Miesi Wilhemsi vervulde echter $\mathrm{Ba}$ Anansi's wensch niet, maar liet den dokter komen, om te onderzoeken, of Ba Anansi ook een kwaal had. Anansi protesteerde hevig tegen zoo'n behandeling, doch Miesi Wilhemsi beweerde, dat het voor zijn eigen best was. Ze gebood hare bedienden hem met geweld te ontkleeden, hetgeen hij sedert zijn huwelijk niet wilde doen. Deze grepen $\ddot{B a}$ Anansi ook aan en begonnen hun werk. Tot haar groote verbazing zag Miesi Wilhemsi, dat uit elke broekspijp twee pooten in plaats van één been te voorschijn kwamen en uit elkę mouw eveneens twee pooten in plaats van één arm. Geheel naakt stond, Ba Anansi dus daar met zijn acht pooten als een gewone spin. En hij schaamde zich zóó erg hierover, dat hij nạar de post'. oro vluchtte, waar hij tot vandaag nog woont. 